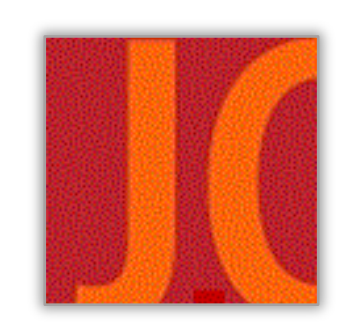

\title{
The Noise of Walking
}

\author{
Twyla Salm \\ University of Regina \\ Lace Marie Brogden \\ Laurentian University
}

\begin{abstract}
:
Walking pedagogies provide opportunities for embracing diversity, at the same time that they honour a relationship with the Earth. As such, they can be used to encourage learners and curriculum makers to attune to their surroundings. Walking and writing together, though from disparate geographical locations, we provoke critical reflections on ableism through walking pedagogies. Inspired by our surroundings, we explicate and query curriculum experiences and the pedagogical reflections that accompany them/us, holding space for (dis)abilities. Coconstructed poetries frame our autoethnographic engagements with theory and practice. We offer two ways walking pedagogies may be engaged to disrupt ableism: walking to "disorient the norm" (Parrey, 2020) in the first instance, and moving as listening in the second. Through these disruptions to ableist discourses, we attend to ongoing circumstances of curriculummaking, attuning to the noise of walking in nature, where some have unrestricted access, some have partial access and some have no access at all.
\end{abstract}

Keywords: ableism; co-constructed autoethnography; curriculum; walking pedagogy 


\section{Le bruit de la marche}

\section{Résumé :}

Les pédagogies de la marche offrent des opportunités pour embrasser la diversité, en même temps qu'elles honorent une relation avec la Terre. En tant que tels, elles peuvent s'utiliser pour encourager les apprenants et les concepteurs de curriculum à s'accorder avec leur environnement. En marcher et écrivant ensemble, bien qu'à partir de lieux géographiques disparates, nous provoquons des réflexions critiques sur le capacitisme à travers des pédagogies de marche. Inspirés par notre environnement, nous expliquons et interrogeons les expériences curriculaires et les réflexions pédagogiques qui les/nous accompagnent, en gardant un espace pour les (dé)capacités. Les poésies co-construites encadrent nos engagements autoethnographiques avec la théorie et la pratique. Nous proposons deux manières d'engager les pédagogies de la marche pour perturber le capacitisme : marcher pour « désorienter la norme » (Parrey, 2020) dans un premier temps, et bouger comme écouter dans le second. À travers ces perturbations des discours capacitistes, nous assistons aux circonstances continues de l'élaboration du curriculum, en accord avec le bruit de la marche dans la nature, où certains ont un accès illimité, certains un accès partiel et d'autres aucun accès.

Mots clés : le capacitisme; l'autoethnographie co-construite; le curriculum; la pédagogie de la marche 
Quand je recommence à écrire... on dirait que j'ai tout oublié, que je ne sais plus comment écrire ... puis je relis des brouillons, des phrases que j'ai écrites dans un calepin ... et je m'arrange pour que le temps soit mon complice.

(Séguin, in Séguin, Bleau \& Gagnon, 2012, n.p.)

In a day after snow, before greening of moss

Walking slowly, intentionally in quarantine, no hurry to return

Attending and attuning to the crunch of fallen birch

Beneath ginger footsteps

$\mathcal{W}$ alking pedagogies offer entry points for critiquing and transforming curriculum, opening up spaces within which to consider and confront ableist discourses. Querying access to walking and nature complements walking-based pedagogies, which "advocate for a notion of curriculum that is lived and emerging, somatic and contextual, personal yet political and enhanced by curiosity and listening" (Feinberg, 2016, p. 150). Specifically, we respond to Feinberg's invitation to "open space to consider the inherent privilege one benefits from if they feel free enough to walk for creative purposes" (p. 159). Through co-constructed autoethnography (Docherty-Skippen \& Brown, 2017; Haywood Rolling \& Brogden, 2009), we write in three voices: together, represented as "our" voice; as Twyla, observing the prairie and walking the Parkland paths; and, as Lace Marie walking the rocks and courting the Canadian Shield. In all instances, we invite readers to stroll alongside us to consider how the mind-body moves with and through nature, challenging taken-for-granted, lived experiences of the past, present and imagined.

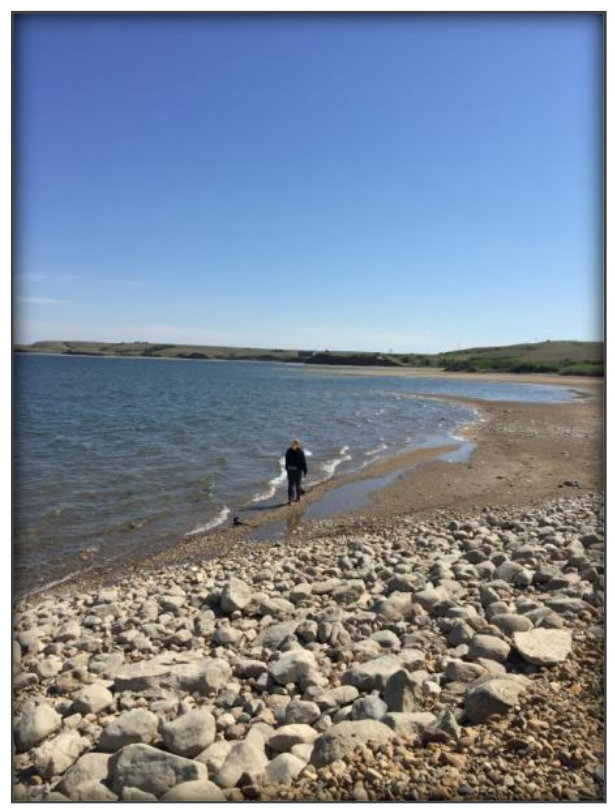

Walking in Landscape. (Photo credit: L. M. Brogden) 
Time has become non-linear

organizing itself in a series of concentric

intersecting circles

a four-dimensional Venn diagram

encapsulating lake, rock, trees, land

Dwelling in landscape

we attune our mind-bodies

to the limitations and possibilities

immersed in a 4-D tour

currering our curricular selves

walking

walking

From our geographic locations on Treaty 6 territory near Nipawin (an anglicized spelling derived from a Nehiyaw word), Saskatchewan, and on Robinson-Huron Treaty at Lake Nepahwin (an Anishnaabemowin spelling), Ontario, our access to nature happens from both privileged and precarious positions. When we think of walking, Butala (1994/2005) resonates for us both:

Day after day, as long as the weather allowed and I was well, I walked the roads and the fields, searching for clues in the susurration [sic] of the wind in the grass and in the boundless layers of sky. (p. 86).

When I walk, down the hill to the lake, past the Saskatoon bushes

chokecherries, cranberries, poplars, birch

drinking in the Parkland vistas carved from glacial remains

my eyes "settle" to the rolling hills beyond

In this place, the wind stays at bay

the air fresh to the point of unremarkable

and only crows and songbirds compete to disrupt

the peaceful

When I walk, up and over scarred, black rock, past the maple saplings

blueberries, lichens, sumac, birch

drinking in the Boreal vistas of lake, shield mottled by shock rock

my eyes "settle" to the horizon of Super stack and impact crater remains beyond

In this place, the wind stays at bay

the humidity balanced to the point of unremarkable

and only loons and forest birds compete to disrupt

the peaceful 
Inspired by aesthetic writing activities (Young, 2018) and life writing (Docherty-Skippen \& Brown, 2017; Hasebe-Ludt et al., 2009; Cixous \& Sellers, 2004), we query what it means to provoke curriculum by attuning to nature and to the privileges and perils of walking for all mind-bodies. $\mathrm{Ng}$ A-Fook (2014) asserts "more work still needs to be done in posing questions of Canadian curriculum studies in relation to the various untold historical and contemporary narratives" (p. 18). Attending to these ongoing circumstances of curriculum-making, we are inspired and aspire to attune to the noise of walking in nature, where some have unrestricted access, some have partial access and some have no access at all. We invite the reader to attune to the noise of walking as a metaphor for que(e)rying ableism in and as curriculum.

When we go out in nature, we are sometimes alone; other times, in addition to negotiating with nature, we negotiate with the other mind-bodies who also seek nature's solace, her regenerative energy and her peace. While walking pedagogies may be defined with terms such as emerging, somatic, contextual and personal (Feinberg, 2016), the term walking also conjures an inherently ableist language that often goes untroubled. Of all the "isms", ableism is under-examined in pedagogical literature, asserts Parrey (2020). Notably, education scholars of disability studies purport they are generally solitary voices in social justice spaces, underscoring how disability is largely absent in curriculum contexts (e.g., Connor, 2019; Nusbaum \& Steinborn 2019). Given the limited entry points in curriculum theory contexts - which extends to teacher education spaces - we share the following definition:

[Ableism is a] pervasive system of discrimination and exclusion that oppresses people who have mental, emotional and physical disabilities.... Deeply rooted beliefs about health, productivity, beauty, and the value of human life, perpetuated by the public and private media, combine to create an environment that is often hostile to those with physical, mental, cognitive, and sensory abilities. (Rauscher \& McClintock, 1997, p. 198)

While inclusive education is now common parlance in educational settings, ableism is not the same as special education or inclusive education. Graham and Slee (2008) ask what it means to be inclusive and how the act of including perpetuates a binary of norm and ab-norm. An example of this binary is illustrated in two photos of the same apple. Depending on one's perspective a round, red apple hanging in a tree might look ripe and perfect. This same apple, however, invaded by wasps, may look imperfect. However, neither version of the same apple is unequivocally perfect nor imperfect. 


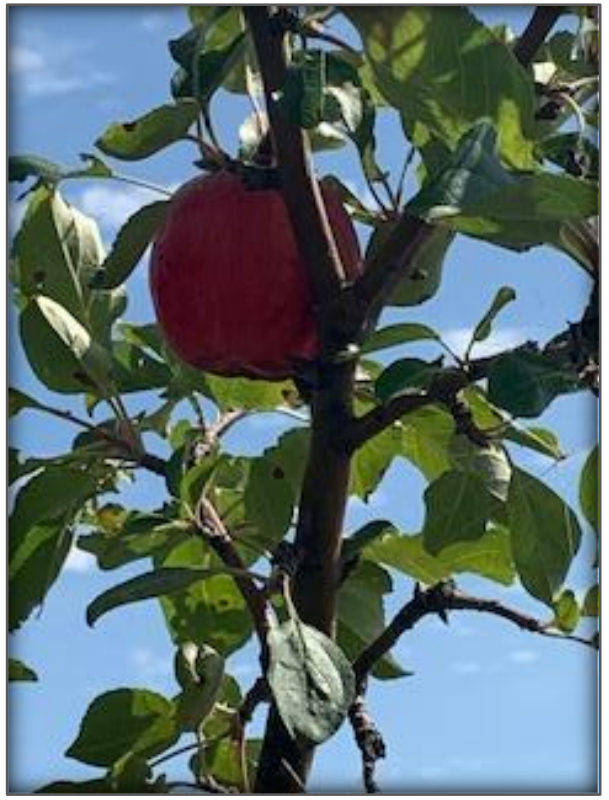

A "Perfect" Apple.

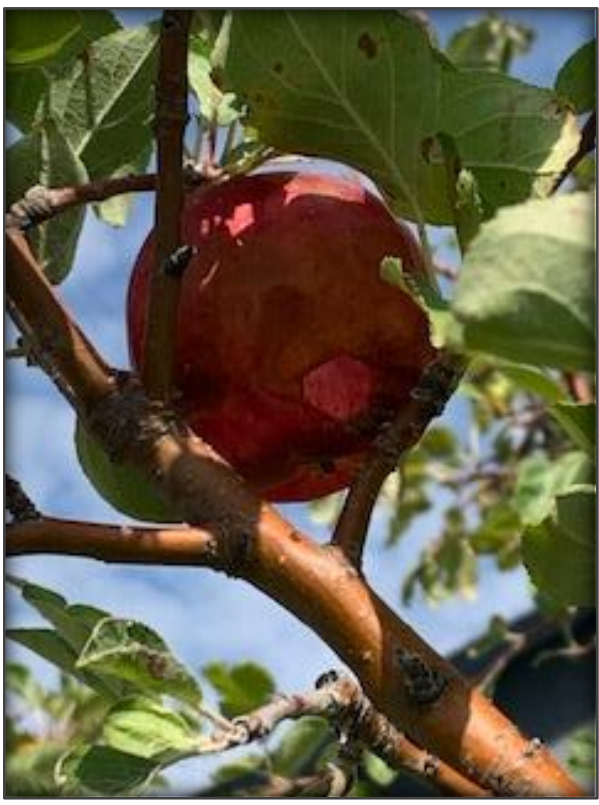

A Perfect Apple for Wasps.

(Photo credit: T. Salm)

\section{Lace Marie-A Story}

At 36 years of age,

I was scheduled for what was to have been

a day-surgery requiring anesthesia. My husband was with me during pre-op,

chatting with me and calming me between iv prep, blood tests and waiting.

Having made many trips to emergency departments in the past,

due to out-of-control asthma attacks, we were both all too familiar with the Ventolin mask the nurse brought over. And yet...

In my life to that point, an emergency trip due to asthma followed a familiar pattern:

breathing gets out of control;

peak-flow meter test reveals lack of lung capacity;

decision to go to emerg is made (not by me);

husband drives me to hospital;

I walk into triage, gasp "asthma-tic-can't-breathe";

without asking for name or health card, I am directed to a treatment room;

I head in the direction I'm told, while a nurse calls the ER doctor;

we three arrive at the same time in the room;

on goes the mask-and somewhere, in the vague background,

I hear someone tell my husband to go check me in. 
In this particular dance of (dis)+ease, I am an actor largely without voice, unable to help myself get better, at the mercy of the reaction times of those around me.

But, on that particular day of my pre-op prep,

I was breathing well (for me) and was otherwise healthy (for me).

And so, when the nurse administered the Ventolin mask,

my healthy (for me) lungs were liberated from their lifelong paradigm of bronchial restriction.

In that moment, the elephant (sometimes Dumbo, sometimes Jumbo)

always sitting on my chest vanished.

I looked at my husband, interrogating,

"Is this always what it feels like when you breathe!?!"

"What do you mean; what's wrong?" he replied.

"Nothing, there's nothing!"

I exclaimed, turning my gaze from his confusion to the nurse, who smiled quietly and said, "Yes."

"Yes, that's what it's like."

That December morning,

in day-surgery pre-op at the Regina General Hospital,

I saw into the world of the able-breathing,

a world where breathing just is.

I knew in those brief moments,

as I still believe today, that the experience had been a gift,

a moment that marked my difference,

by allowing me a few, short hours to breathe without conditions.

I've never had the experience since; but it walks with me, and it shapes the way

I glimpse the struggles of others too often discounted, rendered invisible, or

simply misunderstood in an able-bodied world.

A limitation such as asthma remains largely invisible to able-breathing others. In such contexts, ableism plays on the invisible. Too often, the "norm" fails to create spaces of generosity for mindbodies who walk with invisible (dis)abilities. When working to de-centre the norm, considering all mind-bodies as "normal" may become more achievable if we consider normal as a continuum. An example of such a continuum is illustrated in two photos of the same croci. Depending on one's perspective, a bouquet of colourful croci blossoming in spring is beautiful. These same croci covered in late spring snow are also beautiful. These flowers adapt, indeed, thrive in both environments. 


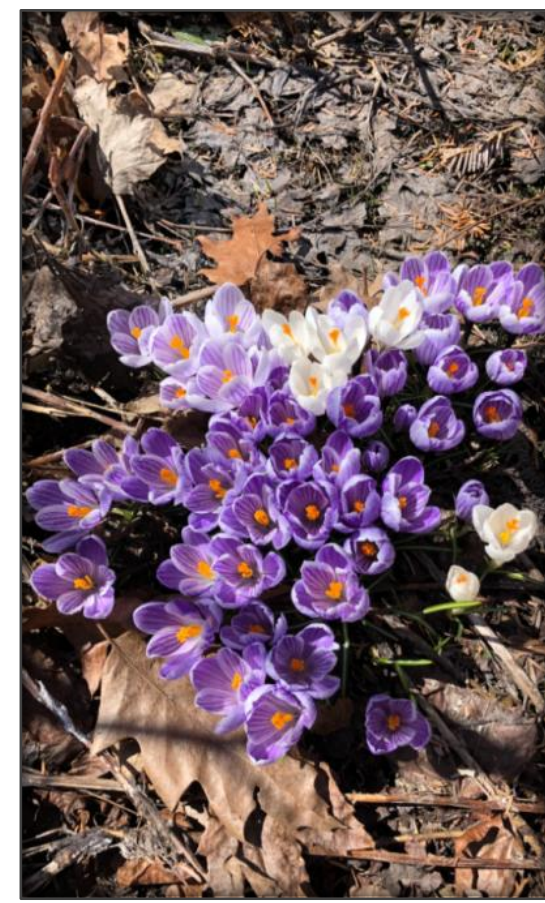

Croci Blooming in Spring Debris.

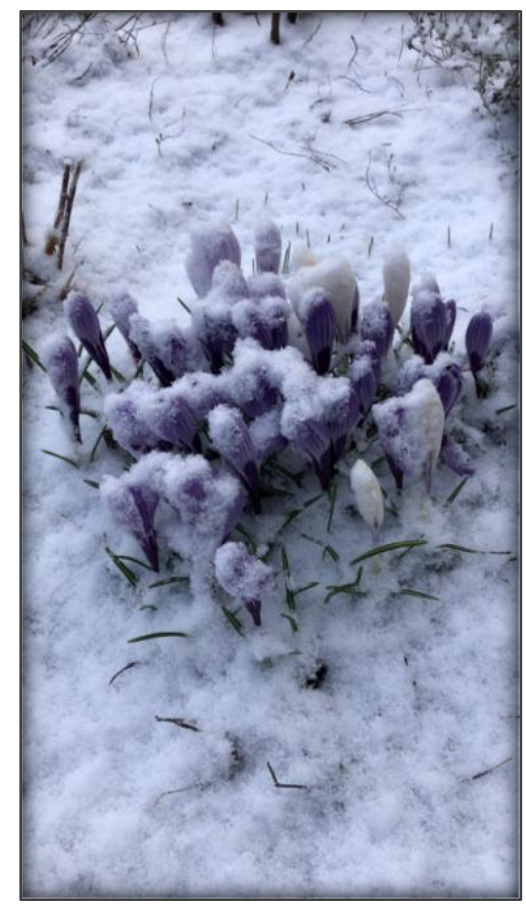

Croci Flourishing in Spring.

(Photo credit: L. M. Brogden)

\section{Twyla - A Story}

As I walked by the bathroom mirror in the morning, I cocked my head to the side, took a look at my face and thought I had slept funny on my face that night. Over the next two or three hours, it became clear that the droop of my mouth, the sagging of the muscles and the unresponsive eyelid was more than a night of pillow damage. By noon, it looked as though I had experienced a massive stroke - the left side of my face unresponsive, while my right side continued as though nothing was wrong. I learned that I was experiencing Bell's palsy, a typically nonpermanent condition affecting only the face and likely diminishing over time. Short of having to watch that I didn't drool and having to use my finger to close my eyelid once in a while so my eye didn't dry out, I felt normal. I carried on as though nothing happened. At first, it was remarkably easy to do so. I did not feel sick; my fallen face did not impede any of my normal daily activities. I recall walking through a mall and my first response to people staring at me was, "Oh crap_is my pant zipper down?"I had forgotten what they could see and what made them stare.

Walking in public spaces was an education. Over time, my relationship with my own identity changed from a woman with a particular appearance to a woman who had less worth as a human being. The fact that my face was no longer even in the realm of what society deemed attractive did not surprise me. I held (and unfortunately often hold) the same socially constructed definitions of beauty and normality as the people who were staring and making comments such as, "If you just look from this direction, you look good." However, I was surprised that there was constant feedback from people- 
both people I knew and strangers - that I was not normal and not competent, in ways which extended far beyond my appearance. It seemed to me that people questioned my decision-making abilities, problem-solving skills and independence, in ways that were not familiar.

Unlike invisible (dis)abilities, visible conditions are omni-discernable to others. Ableism plays on this visibility. Once again, the norm too often fails to create spaces of generosity for mind-bodies who walk with visible (dis)abilities. Confronting ableism cannot be reduced to a question of invisible or visible, just as it cannot be reduced to a question of ability or disability: we are all able and not able in certain times and certain spaces. Disrupting ableism, therefore, is about more than being kind to and accepting of people with (dis)abilities; rather, it is about challenging both the narrow spectrum of what is considered "normal" and the deficit thinking that too often defines people with (dis)abilities.

Thus, the challenge for educators lies in confronting normalizing discourses, which produce some mind-bodies as needing inclusion. Graham and Slee (2008) argue that suggesting these subjects must be brought into a normalizing centre is a trope, as the normalizing centre is a fictional place. In this way, ableism creeps into inclusion-even as the rhetoric of equitability and inclusivity in education are vigorously promoted. This creep is so pervasive that there is a term to describe it: dysconscious ableism. As defined by Broderick and Lalvani (2017), dysconscious ableism represents the limited and distorted ways that most teachers understand (dis)ability and "tacit[ly] accept dominant ableist norms and privileges" (p. 896). It is often difficult for so-called able-bodied scholars to think beyond an ever-present normalizing lens. Nevertheless, as curriculum theorists, we must attend to asking how we can seek to "disorient" (Parrey, 2020) the proliferation of the idealized mind-body discourse. "Disorientation", according to Parrey (2020), privileges practices that are "at once disruptive, revelatory, and potentially transformative" (p. 40). Inspired by Parrey's work, we use a critical gaze to better understand ways ableism is produced and maintained in curriculum contexts. Walking pedagogies offer a creative way to take up this challenge, providing avenues for disorienting ableism in ways that interrogate the landscape and access to it. In this way, we accept Feinberg's (2016) invitation to consider her work "as a continuum" (p. 163) and propose enacting walking pedagogies as counternarratives to dominant ableist discourses, repositioning disability "as a source of knowledge and cultural wealth" (Nusbaum \& Steinborn, 2019, p. 26). 


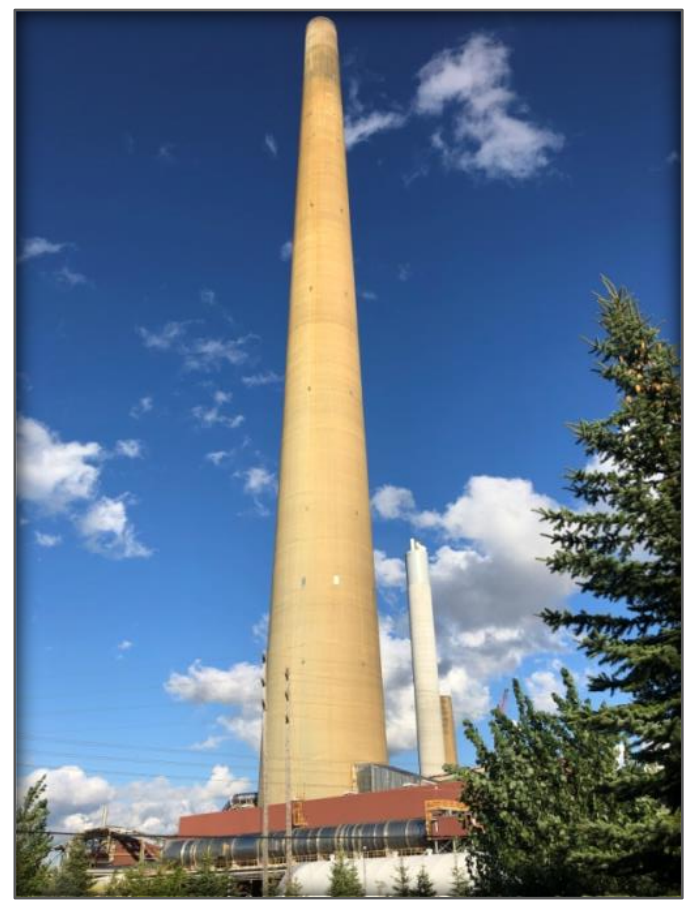

The Sudbury Super Stack, View From Copper Cliff. (Photo credit: L. M. Brogden)

If you look up at the Super stack on a sunny day

the clouds stand still

leaving its imposing height to sway toward you

A (dis)abling destabilizing sort of reverse vertigo

demands you look away

lest the weight of the stack should fall

crushing you into the hillside

the meteor left in its wake

Bringing walking pedagogies into teaching spaces offers opportunities for students to experience walking in ways that expand what we acknowledge as typical. Disrupting the very term walking is one such pedagogical disorientation. The words we use in "walking pedogogies" risk reinforcing the privilege of those who walk over those who roll-perpetuating the ableist binary. One could, for example, replace walking pedagogies with moving pedagogies, but the lack of suitable synonyms only serves to emphasize how language produces inequities, constructs social hierarchies and denies rights to certain bodies. Therefore, we advocate approaching walking pedagogies with creativity, attuning to both nature and the ways it can be experienced. The teacher as curriculum creator is well-positioned to do this work:

Teachable moments" hint at opportunities for teachers to act as public intellectuals.... [These moments] are difficult to contain in the classroom, and have a habit of resonating beyond its 
four walls. "Students" walk away not simply with "content" knowledge, but with a mode of relating to knowledge. (Hsu \& Paek, 2012, p. 13)

\section{Walking to Disrupt the Norm}

I (Twyla) stumbled onto the value of walking pedagogies as a strategy to help adult learners self-regulate. Faced with a summer-intensive course that brought me together with my graduate students for nearly six hours each day, I invoked a version of walking pedagogy as a way to reinvigorate students during the brain slump that often comes after lunch. I provided students with four long "trails" that took them to different parts of the campus, accessing both indoor and outdoor spaces and highlighting various places and features along the way. Each day, alone or in groups, students walked along on a path they had chosen, and then returned to our class to debrief. My instructions were specific: "Attend to the ways ableism is produced and maintained in and around our campus." I also asked the students to identify places and spaces of disruption, and to que(e)ry how all of these observations connected to their own pedagogical beliefs.

The walking trails were diverse. They moved through quiet spaces, such as chapels and allgender bathrooms, as well as through crowded spaces, such as student services, the accessibility centre and the women's centre. There were also outdoor trails, past the campus grounds and into grassy park areas that house sculptures. Each trail offered a multitude of prompts to reveal ablebodied privilege, as well as explicit disruptions:

"Where is that elevator?

Is there perfume in the air? That is one big open space!

Can I maneuver on this uneven ground? There is a lot of noise all of a sudden! Who is here with me? Who is absent from this space?"

As we discussed the students' observations, it was not easy to talk about ableism, as we were drawn to language that often reiterated an able/disabled binary. Try discussing ableism without differentiating between an able body and a "not able" body!

The paradox was not lost on my students.

We talked about how labelling bodies invokes hierarchies that create oppressions, while at the same time, how labelling also legitimizes some bodies and makes particular impairments visible; parents and teachers in the group were keenly aware of how often "visibility" was/is necessary for advocacy, resources and funding. Using walking pedagogies afforded my students opportunities to experience how ableism is produced and disrupted in real-life contexts. By inciting them to attune to their surroundings, they could relate ableism to their own lives and pedagogical settings, and ask curious questions, and point out dilemmas and paradoxes that might not otherwise have emerged.

The example just given "disorients" the landscape as a pedagogical strategy for building counternarratives. Another disorientation of walking pedagogies in the classroom is to adopt a critical lens when considering hearing and listening. Feinberg's (2016) definition of walking 
pedagogies focuses on listening as one of the key senses for learning in nature. For hearing students, listening is often a tool used for engaging in cognitive and emotional learning and a primary medium through which they come to know the world and experience various landscapes. Listening, however, is not the same as hearing; they are often differentiated by the reflection and mindfulness that comes with listening. Nevertheless, both are typically associated with aurality. We propose that walking pedagogies can offer a unique attunement to ways of walking, moving and listening that do not rely on sound waves entering the ears. Gallagher et al. (2017) suggest that all bodies would benefit from understanding a broader application of listening in what they call expanded listening, which addresses how human and more-than-human beings respond to sound (p. 618). They argue that listening can also include sonic effects (such as vibrations), bodily sensations and emotions, and that such effects and experiences can be unrelated to cochlear reception. Rather than asking what sound is, they ask what sound might do to or within the mind-body. They explain: "developing listening practices may therefore be less about becoming newly responsive to sound, and more about attending more closely to responses that are already happening, but which normally pass unnoticed; put another way, listening to bodies listening" (Gallagher et al., 2017, p. 622). Thus, disrupting ableist discourse by attuning to moving in nature allows the teacher-as-curriculum-maker to imagine and enact more complex and robust activities while using walking pedagogies.

By way of example, the activity below engages walking pedagogies as a means to disrupt ableist perspectives. While walking down a trail, such as the one shown in the photograph, we might ask of our students: "Listen. What sounds might you attune to when you are walking down this trail?" Students who rely on cochlear reception might note the leaves rustling while a deaf person might note the flicker of light passing through the leaves or the slight vibration of thunder in the distance that might not be audible to others. Walking down a trail in nature, even at the same time and place, is a unique experience for every person. We do not all hear, see, smell or feel in the same ways, even in the same moments. Senses are influenced by experiences and evoke memories that are personally constructed. Walking pedagogies can embrace this diversity while honouring a common relationship with the Earth, encouraging students to attune to their surroundings in new ways and to acknowledge and embrace the attunements of others. 


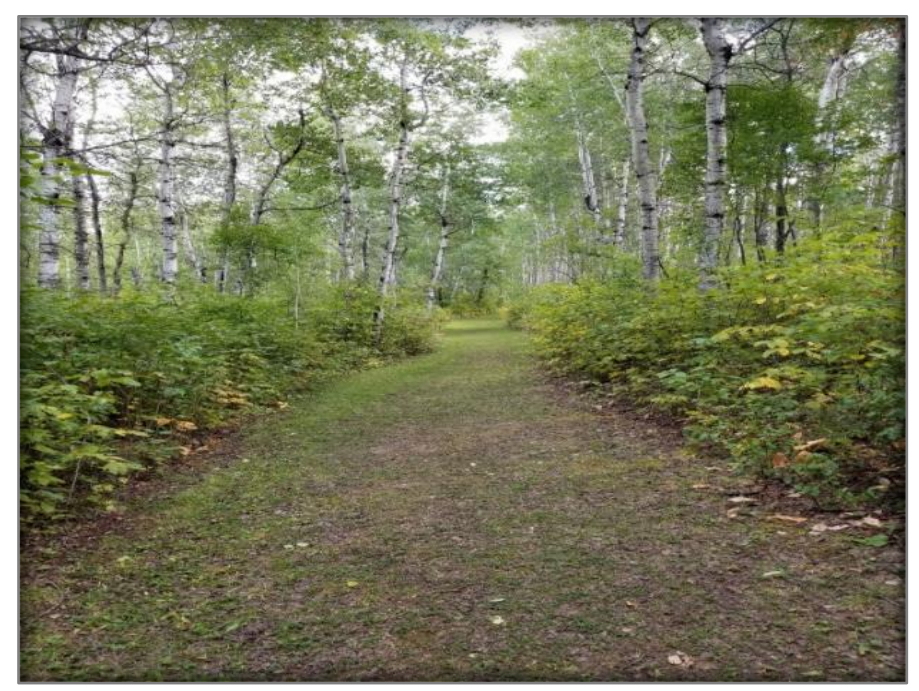

A Parkland Path. (Photo credit: T. Salm)

\section{What Might You Attune to While Walking Down This Trail?}

\section{A hearing person might attune to:}

the clap of thunder

the crack of a twig

the rustle of leaves

the whistle of wind
A person with various levels of hearing might attune to: the vibration of thunder in the distance the snap of twigs breaking underfoot the flicker of light through the leaves the drift and smell of pollen and dust

Different abilities allow learners and teachers to attune to nature in different ways. Just as intended through our discussion of in/visibility, the listening activity is designed to provoke curricular decisions teachers make when they expand their own practices in talking up walking pedagogies. Our walking intentionally - together and apart-has pushed us to reflect critically on the ways our own mind-bodies move through nature and the impact this has on our work with teacher candidates and with teachers. 


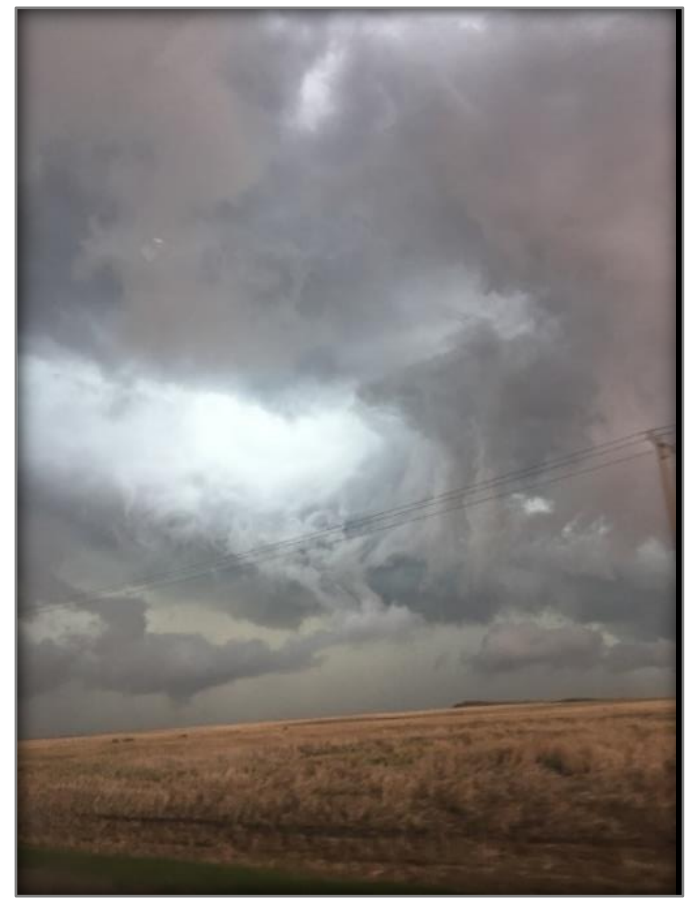

A Prairie Storm. (Photo credit: L. M. Brogden)

Some days my body feels broken

from the inside out

Like a swallow or hummingbird in a Lorna Crozier poem

Wounded or damaged, wings clipped

Of course, whenever Lorna writes of those birds

I always read them as women

Those who've buried

their own children

their secrets

their pain

Weathered like my Gram

But never quite worn

Out rising again

Face full to the prairie storm

The operation and maintenance of ableism happen by systematically and actively erasing disability, and therefore erasing certain mind-bodies (Nusbaum \& Steinborn, 2019). In this article, we have focused on how walking pedagogies may be taken up with a view towards disorienting ableism (Parrey, 2020). Walking pedagogies are very much attuned to land and to being in nature, 
encouraging "walking with mindful awareness" (Feinberg, 2016, p. 151). As former K-12 teachers and now members of faculties of education, we continue to see the world through the next lesson we might teach. The noise of walking serves as a metaphor for the potential for walking pedagogies to be critical and to interrogate normalizing discourses that serve to oppress mind-bodies. We hope that the teaching ideas proposed here will expand the potential for walking pedagogies and will contribute the noise-the loud disturbance-that is needed to disrupt ableist discourses that run rampant in pedagogical spaces. Embattled yet still hopeful (Jardine, 2018), we extend an open invitation to the reader, the teacher, the scholar and the walkers to attend to the noise.

In a day before snow, after greening of moss

Currere forward an intentional, critical pedagogy

Attending and attuning to relationality

Amplifying restorative footsteps

\section{About the Authors}

Twyla Salm is a full professor and serves as Associate Dean, Research and Graduate Programs, in the Faculty of Education at the University of Regina. Her research focuses on teaching and learning in higher education, with specific interests in developing the professional educator, in health education and in curriculum studies.

Lace Marie Brogden is a full professor and serves as Dean of the Faculty of Education at Laurentian University. Her research interests include language teacher education, negotiating subjectivities, social justice in education and autoethnography as method.

\section{References}

Broderick, A., \& Lalvani, P. (2017). Dysconscious ableism: Toward a liberatory praxis in teacher education. International Journal of Inclusive Education, 21(9), 894-905. https://doi.org /10.1080/13603116.2017.1296034

Butala, S. (2005). Perfection of the morning: An apprenticeship in nature. Harper Collins.

Cixous, H., \& Sellers, S. (Eds.). (2004). The writing notebooks of Helene Cixous. Continuum.

Connor, D. J. (2019). Why is special education so afraid of disability studies? Analyzing attacks of disdain and distortion from leaders in the field. Journal of Curriculum Theorizing, 34(1), 10-23. https://journal.jctonline.org/index.php/jct/article/view/763/384

Docherty-Skippen, S., \& Brown, H. (2017). Challenging the status quo: The evolution of the supervisor-student relationship in the process of potentially stigmatizing and emotionally complex autoethnographic research. Journal of the Canadian Association for Curriculum Studies, 15(1), 54-71. https://www.researchgate.net/publication/322103340

Feinberg, P. P. (2016). Towards a walking-based pedagogy. Journal of the Canadian Association for Curriculum Studies, 14(1), 147-165. https://jcacs.journals.yorku.ca/index.php/jcacs/article /view/40312/36186 
Graham, L. J., \& Slee, R. (2008). An illusory interiority: Interrogating the discourse/s of inclusion. Educational Philosophy and Theory, 40(2), 277-293. https://doi.org/10.1111/j.14695812.2007.00331.x

Hasebe-Ludt, E., Chambers, C., \& Leggo, C. (2009). Life writing and literary métissage as an ethos for our times. Peter Lang.

Haywood Rolling, J., \& Brogden, L. M. (2009). Two hours or more away from most things: Re:writing identities from no fixed address. Qualitative Inquiry, 15(7), 1139-1154. https://doi.org/10.1177 /1077800408314342

Hsu, R., \& Paek, J. (2012). "Way too Asian!". In D. Bhandar, J. Heer, R. J. Gilmour, \& M. C. K. Ma (Eds.), "Too Asian?": Racism, privilege, and post-secondary education (pp. 95-103). Between the Lines.

Jardine, D. W. (2018). To know the world we have to love it. In E. Hasebe-Ludt \& C. Leggo (Eds.), Canadian curriculum studies: A métissage of inspiration/imagination/interconnection (224-225). Canadian Scholars.

Gallagher, M., Kanngieser, A., \& Prior, J. (2017). Listening geographies: Landscape, affect and geotechnologies. Progress in Human Geography, 41(5), 618-637. http://dx.doi.org.libproxy. uregina.ca/10.1177/0309132516652952

Leggo, C. (2009). Living love stories: Fissures, fragments, fringes. In M. Prendergast, C. D. Leggo, \& P. Sameshima (Eds.), Poetic inquiry: Vibrant voices in the social sciences (pp. 147-167). Sense.

$\mathrm{Ng}$-A-Fook, N. (2014). Provoking the very "idea" of Canadian curriculum studies as a counterpointed composition. Journal of the Canadian Association for Curriculum Studies, 12(1), 10-69. https://jcacs.journals.yorku.ca/index.php/jcacs/article/view/37169

Nusbaum, E., \& Steinborn, M. (2019). A "visibilizing" project: "Seeing" the ontological erasure of disability in teacher education and social studies curricula. Journal of Curriculum Theorizing, 34(1), 24-35. https://journal.jctonline.org/index.php/jct/article/view/764

Parrey, R. C. (2020). Embracing disorientation in the disability studies classroom. Journal of Literary \& Cultural Disability Studies, 14(1), 37-56. https://doi.org/10.3828/jlcds.2019.16

Rauscher, L., \& McClintock, J. (1996). Ableism curriculum design. In M. Adams, L. A. Bell, \& P. Griffin (Eds.), Teaching for diversity and social justice (pp. 198-231). Routledge.

Séguin, R., Bleau, M., \& Gagnon, E. (2012). Ma demeure: Anthologie [Box Set]. Spectra Music.

Young, K. (2018). The character of contemporary curriculum studies in Canada: A rumination on the ecological and metaphorical nature of language. In E. Hasebe-Ludt \& C. D. Leggo (Eds.), Canadian curriculum studies: A métissage of inspiration/imagination/interconnection (pp. 78-86). Canadian Scholars. 